\title{
Regional management of the Bay of Bengal water area. \\ The challenges of maritime security
}

Nafisa Yeasmin, PhD

Arctic Centre, University of Lapland, Finland

Pavel Tkach, LLM

Arctic Centre, University of Lapland, Finland

\section{Abstract}

The Bay of Bengal is the largest bay in the world that forms the northeastern part of the Indian Ocean, bordered mostly by the Eastern Coast of India, southern coast of Bangladesh and Sri Lanka to the west and Myanmar and the Andaman and Nicobar Islands (part of India) to the east. The regional management of the Bay of Bengal water area is performed by regional organisations such as ASEAN, SAARC, BIMSTEC and IORA unifying Bay's coastal states. Nevertheless, differences in political and economic interests of the states, separate conflicts between states and consequences of the pandemic not only challenged the integrity of the regional management but also led to rising insecurity of the Bay of Bengal and fears to navigate in that area. In this article, the authors, in a more detailed way, will disclose existing regional management systems, concerns related to maritime security and give recommendations on how to increase efficiency in collective management of maritime security issues and how the concept of due diligence may play the vital role in the regulation of not only maritime security aspects but also aspects of environmental protection and potential transition to the blue economy.

Keywords: Bay of Bengal; maritime security; regional cooperation; due diligence.

\section{Introduction}

Today, the Bay of Bengal countries account for a population of almost 1.78 billion, while adjacent states with interest account for an additional 490 million. The core states have a combined GDP of $\$ 7.5$ trillion, with interest-bearing states adding another $\$ 811$ billion. More robust governance is required to solve maritime security challenges in the Bay of Bengal in today's heightened geopolitical and epidemiological circumstances in the region and around the world (BoB). Nevertheless, economic proficiency is not the only concern of international governance. The important challenge that the regional interstates organizations in the Bay of Bengal water area face is maritime security. Maritime security is a general term that refers to the internal and external security of navigation. Piracy, illicit trade, and maritime mixed migration pose threats to navigation in the Bay of Bengal (Benson, 2020). 
Geopolitically, the littoral countries of BoB face tensions and crises that have been unsolved for many years, like political unjust situation between India and Pakistan, the Rohingya crisis of between Bangladesh and Myanmar, etc. These geopolitical tensions impact mutual trust, respect and equitable sharing of benefits among regional states. (Rahman, 2017). Regional cooperation between these littoral countries to manage maritime security has many advantages likely to manage oceanic affairs and participation of regional countries in the negotiation tables etc. (Rahman, 2017). On the other hand, there is no binding reporting and monitoring system among the littoral states (Rahman, 2017). However, regional ocean governance lacks common strategic priorities since the strategic priorities of the coastal states vary based on their national priorities, depending on their national political aspects. Therefore, littoral countries are not equally following proper stepping for protecting the marine environment, likely marine pollution, illegal fishing etc. (Sakhuja, 2014). Sharing of information about aquatic resources, experiences and practices of Blue Economy requires a common strategy requiring better collaboration (Rahman, 2017). Such information sharing has also been recommended in the working session with high importance in the third IORA (Indian Ocean Rim Association) ministerial Blue Economy conference (IORA, 2019).

Proper utilization of an ocean-based economy encompasses sustainable usages of marine resources. The concept of the blue economy (BE) was promoted at the Rio Summit in 2012 (Rahman, 2017). The blue economy encompasses many activities that impact livelihoods and jobs of human beings, and activities established based on the exploitation of aquatic resources (World Bank, 2017). The World Bank stated to preserve the health of marine and coastal ecosystems while using the aquatic resources. Furthermore, BE governance has been substantial for the littoral and non-littoral states in matters of preserving a healthy coastal ecosystem (Attri and Muller, 2018).

The blue model of $B o B$ is unlikely to deliver a truly balanced integrated model for the littoral and non-littoral states unless agreeing upon a common and convenient definition of cooperation that can facilitate reasonable utilization of marine resources of respected countries. (Singh, 2020). The sustainable practices of the BoB region need special attention keeping the geopolitical tensions of littoral states in mind. The $4^{\text {th }}$ ministerial summit in 2018 in Kathmandu (BIMSTEC summit, 2018) discussed the healthy usages of the marine resources, and the monitoring of such activities related to exploitation of ocean resources are agreed to be enhanced further. The initiative of motoring remains in the institutional capacity of the Bay of Bengal Initiative for Multi-Sectoral Technical and Economic Cooperation BIMSTEC (agreement no. 9 of institutional reform in the Fourth BIMSTEC Summit Declaration at Kathmandu).

Blue growth of BoB needs a monitoring context to secure the holistic manner to ensure regional cooperation (Rahman, 2017), which has long been discussed for implementation. In fact, India is planning to get a separate new ministry to deal with BE (Singh, 2020), 
which is a holistic approach for India to way forward for fair usage of aquatic resources. However, the Blue movement needs from all littoral states of BoB to ensure sustainable practices among BoB governance.

Therefore, the article evaluated how the Bay of Bengal coastal states deal with maritime security issues and how they do that within the agenda of the regional organisations. The operation of regional organizations was examined with special attention paid to the due diligence concept, which imposes an obligation on states to maintain safety within or outside their respective borders in order to prevent detrimental occurrences. And we concluded with the recommendations to regional cooperation in the Bay of Bengal on how to make maritime security regulation more effective and which role due diligence can have in Bay of Bengal regional management?

\section{Maritime security regime $\&$ cooperation}

The BoB governments are aware of maritime security agendas. Increasing oil and gas demands, economic resilience, increased connectivity for trades and supply are the pushed factors for boosting maritime cooperation between littoral and non-littoral states. Maritime security has been a top priority for states with significant economic and political clout. (Jack and William, 2010) (Bueger and Edmunds, 2017).

The concept of maritime security is a distinct subcategory of the law of the sea that incorporated mainstream security issues, domains and activities to develop multisectoral cooperation on common ground to secure transnational organised crime or environmental degradation (Bueger and Edmunds, 2017). Maritime security accentuates how crucial international collaboration is in expanding the notion of security among coastal states and states interested in exploring and exploiting water areas.

Indeed, cooperation is needed to protect the security of the Bay of Bengal. Maritime security management has been a potential prospectus fact for increasing blue economy and strategic significance (Gamage, 2017). International organisations assisting the implementation of maritime security management of BoB are:

\section{- BIMSTEC}

This sub-regional organization BIMSTEC was established in 1997 after Bangkok Declaration. The acronym BIMST (Bangladesh, India, Myanmar, Sri Lanka and Thailand, EC economic cooperation) ended up with the Bay of Bengal Initiative for Multisectoral Technical and Economic Cooperation in February 2004. There are many sub-sectors BIMSTEC works for by facilitating cooperation between its member states. The permanent secretariat was established in Dhaka, 2014. There are sectoral committees coordinate, monitor and review progress by meeting, organizing summits to reconnect private/public and regional/international concerned bodies. 


\section{- SAARC}

The secretariat of SAARC was established in Kathmandu in 1987. SAARC has an arbitration council in Pakistan. The fair and efficient settlement of issues and other relevant disputes within the region might be referred to the arbitration council. There are currently nine observers of SAARC along with Australia, China, EU, Iran, Japan, Korea, Mauritius, Myanmar and the USA. Maritime cooperation is one of the many priority areas of SAARC. Many successful agreements have been conducted under this framework. Though maritime issues were ignored to some extent, e.g. mitigating environmental and human development concerns of the Bay of Bengal (Iyer, 2017) because of the imbalance of power between littoral countries and their connectivity and integration (Benson, 2020). The $18^{\text {th }}$ SAARC summit in Nepal recognized the potentials of a blue economy in the region. Bangladesh seems to be the country recognized vision of BoB Partnership for Blue Economy and pushed forward to ensure sustainable development and management among littoral states (Rahman, 2017). Some of the monitoring desks regarding SAARC criminal matters have been blocked by Islamabad due to the political relationship between India and Pakistan (Bhaumik, 2018).

\section{- IORA}

Priority areas are maritime safety and security, fisheries management, disaster risk management, trade and investment facilitation etc. Recently Bangladesh hosted a high-level conference in Dhaka on IORA Blue Economy in September 2019. Enabling global connectivity requires acknowledging the criticality of the maritime infrastructure was discussed in the $6^{\text {th }}$ Indian Ocean Dialogue, 2019 event in Delhi. Indo-Pacific maritime issues require cooperation along with common understanding is the main dialogue of the IORA. (The Delhi Consensus, 2019) India, Sri Lanka, Bangladesh, Thailand are the members of both BIMSTEC and IORA. IORA Council of Ministers, senior officials' committee, and Troika are the governance bodies. High-level meetings, conferences and working group reports are maintained in the IORA strategic planning on ocean management, sustainability and security.

\section{- ASEAN}

The Association of Southeast Asian Nations (ASEAN) was founded on August 8, 1967, when the foreign ministers of five countries signed the ASEAN Declaration: Indonesia, Malaysia, the Philippines, Singapore, and Thailand. From the foundation, one of the priority areas of the ASEAN was maritime security. The ASEAN recognizes the multifaceted nature of marine issues and pledges to handle them in a holistic, integrated, and complete manner. More specifically, ASEAN prioritises combatting sea piracy as a form of transnational crime linked to other forms of transnational crime, such as terrorism, illicit drug trafficking, illicit trafficking of wildlife and timber, trafficking in persons, and people 
smuggling (ASEAN, 2018). Through the strengthening of ASEAN-led mechanisms and the adoption of internationally accepted maritime conventions and principles of maritime cooperation and maritime security, a resilient community in a peaceful, secure, and stable region has been built, with enhanced capacity to respond effectively and quickly to challenges in the field of maritime security (ASEAN, 2018). One of such mechanisms is the ASEAN Security Community (ASC) (nowadays ASEAN Political-Security Community) was initiated by Indonesia and adopted as part of the Bali Concord II in October 2003 and can be defined as the system of regular meetings resulting in issuing strategic documents. More specifically, maritime security issues are discussed at ASEAN Defense Ministers Meetings-Plus. So, within the agenda of the mentioned international organization, maritime security is a regular topic (ASEAN, 2018).

\section{Importance of the BoB region and its opportunities and challenges}

BoB serves the dynamics of the macroeconomic growth engine of the region. The third IORA conference in BE in Dhaka was the platform to discuss the opportunities of utilizing marine resources for the macroeconomic growth of littoral and non-littoral states. This "Dhaka Declaration on BE" serves as a way forward to the blue model of economy. This declaration opportune member states for reaping economic benefits by including features of oyster culture, marine flora and maricultural (IORA, 2019). BE growth of the BoB region significantly influences the increasing GDP of littoral and non-littoral states (Karim, 2021). The trade shares of SAARC countries are $5 \%$ of global trade from Blue Economy of $\mathrm{BoB}$, which is $25 \%$ among ASEAN countries, EU \& North America boast $40-50 \%$ from BoB (Karim, 2021). Subsequently, the BoB zone is not only boosting the economy in the region but also influences boosting the economy of the EU, North America and Asia. Economically healthy countries are utilizing the benefits of $\mathrm{BoB}$ than the littoral countries. Many economic activities are encompassed in the domestic strategic priorities of BoB states, likely shipping, energy productions, tourism, fisheries, maritime trade etc. The littoral states need to rediscover the importance of the BoB for better livelihoods by utilizing BE of the BoB zone. The GDP growth rate of Bangladesh, Myanmar and India is faster than Nepal, Sir Lanka, Bhutan and Thailand (Chaudhary, 2021).

The most challenging part of the BE of the zone in the weaker domestic economy of some of the countries make obstacles for equal participation and utilizing economic benefits. (Singh, 2020: Rahman, 2017: Chaudhary, 2021). Corruptions, rigid national policies, and lack of information flow among the countries are the most challenging part. Lack of information on marine resources needs a knowledge sharing scope between countries. Many countries lack control over the legal and environmentally friendly utilisation processes, creating an unhealthy ecosystem and polluted BoB. Research 
and development funds are not available, which hinders the rediscovering of the BoB zone and its economic and ecological value of fueling domestic trade and global trade opportunities. (Karim, 2021). Though consistent targets and interest for a Sustainable Blue Economy were recommended in the IORA 2019 conference. The $4^{\text {th }}$ BIMSTEC summit emphasized the necessity for generating an Inter-governmental Expert Group who can make an action plan on the blue economy is the hope for the future development of the marine ecosystem of the BoB.

\section{Role of International Organizations: Challenges and opportunities}

Bay of Bengal Initiative for Multi-sectoral Technical and Economic Cooperation (BIMSTEC) plays a reading role in promoting cooperation among their member countries: Bangladesh, Nepal, Bhutan, India, Shri Lanka, and Myanmar and Thailand. Issues such as piracy, overfishing, climate, and geographical positions of some countries disrupt and hinder satisfactory results of the cooperation among states (BIMSTEC). The governments of the Bay of Bengal states have been trying to solve mentioned problems by ratifying and signing many international maritime treaties that fail to manage the potential conflict to many extents (BIMSTEC). The socio-economic imbalance between the states hinders the capacities of the states to protect their national marine security, capacity to build climate resilience and economic growth. For example, the UN Food and Agriculture Organization's Bay of Bengal Large Marine Ecosystem (BOBLME) project, which ran from 2009 to 2017, encouraged capacity development by integrating knowledge through need assessments. (BOBLME, 2016) (Benson, 2020). However, the project lacked coherency in facilitating leadership driving initiatives. Modelling ecosystem management was challenging for the project, and the project summarized a need for an effective and sustainable management system across the region (BOBLEM, 2016).

BIMSTEC enhanced regional cooperation and created a platform for securing the Bay of Bengal. Nevertheless, within the cooperation, there are still challenges to improving safety procedures. Member nations and their internal interests posed challenges. Nepal and Bhutan are landlocked countries with a vested interest in the Bay of Bengal's maritime stability (Benson, 2020). The second BIMSTEC emergency management exercise was carried out in February 2020: 80 delegates from Bangladesh, India, Myanmar, Sri Lanka and Nepal, along with 35 Indian State representatives, followed the exercises. Emergency prevention and management in the Bay under BIMSTEC has been controlled effectively through strong financial commitment, which is hard to get from the respective countries (Bose, 2020) due to the absence of consolidated funds to run the further projects aimed at security control (Godbole, 2018) (Xavier, 2018). Resource commitment is one of the main policy priorities to secure maritime issues that some economically solvent countries are not ready to provide, and others lack limited 
economic solvencies towards regional developmental instruments (Gamage, 2017). Another priority area of planning is improving the maritime surveillance capacity of ports and navigating states. Gathering information about maritime accidents and maritime welfare objectives requires developing surveillance systems. Lack of capacities and control over corruption hinder the inspections of cargo by respective authorities. $90 \%$ of world cargo is transported through the Indian ocean, and only $2 \%$ of physical inspection activities conducted by the authorities cause illicit activities (Alam, $\mathrm{n} / \mathrm{d}$ ). Networks and friendly relationships between sovereign states and authorities need access to all sources of information and missions at sea that possible to integrate and improve existing surveillance systems. Regarding the mentioned promotion of technologies as a component of constructing friendship between states, Article 268 of UNCLOS defined that states, directly or through competent international organisations, shall promote: the acquisition, evaluation and dissemination of marine technological knowledge and facilitate access to such information and data, the development of appropriate marine technology, the development of the necessary technological infrastructure to facilitate the transfer of marine technology (UNCLOS, 1982). We would like to note that cooperation in maritime security through information and technology exchange is acceptable and highly recommended by international law.

The rule of law on this maritime zone challenges to enable integrity campaigns between littoral states. Nevertheless, the uniformity of criminal law, commercial law, and public international law is essential to protect judicial integrity. And nowadays, there are crucial infrastructural differences between different BoB port areas that take place, mainly due to differences in corruption rates and the rule of law acceptance. In response to such challenges, India has taken the initiative by creating the Maritime Anti-Corruption Network (MACN), where over 100 private companies work together to tackle maritime security (BIMSTEC).

\section{Managing Complexity of BoB governments}

The core governments of the $B O B$ that are part of BIMSTEC require initiatives to produce a coherent approach to secure the BoB zone. As all of the core governments are not part of IORA, SAARC and ASEAN, this created a necessity to develop a diverse level of coordination in maritime security governance for some member states. It also brings a heterogeneous set of actors in coordination management that might create complexity in maritime governance.

So, the BoB governments need to build capacities and standardize domestic maritime security welfare policies since ocean governance, economic resilience, and security level at sea vary between states (see table 1, 2 \& 3). 


\begin{tabular}{|l|l|l|l|l|}
\hline $\begin{array}{l}\text { Littoral } \\
\text { Countries }\end{array}$ & $\begin{array}{l}\text { Piracy and armed } \\
\text { robbery (scores in } \\
\text { average) }\end{array}$ & $\begin{array}{l}\text { Illicit trades } \\
\text { resilience } \\
\text { (scores in average) }\end{array}$ & $\begin{array}{l}\text { Maritime Mixed } \\
\text { migration (scores in } \\
\text { average) }\end{array}$ & $\begin{array}{l}\text { Security at sea } \\
\text { (scores in average) }\end{array}$ \\
\hline Bangladesh & 19 & 65 & 47 & 44 \\
\hline India & 24 & 48 & 64 & 45 \\
\hline Myanmar & 44 & 53 & 37 & 45 \\
\hline Sri Lanka & 84 & 61 & 55 & 67 \\
\hline Thailand & 78 & 57 & 53 & 63 \\
\hline
\end{tabular}

Table 1: Security at the Sea (Digits indicate navigation safety in waters: ascending from dangerous to safe (0 to 100) $)^{1}$

\begin{tabular}{|l|l|l|l|l|}
\hline $\begin{array}{l}\text { Littoral } \\
\text { Countries }\end{array}$ & $\begin{array}{l}\text { Coastal welfare } \\
\text { (scores in } \\
\text { average) }\end{array}$ & $\begin{array}{l}\text { Blue Economy } \\
\text { (scores in average) }\end{array}$ & $\begin{array}{l}\text { Fisheries (scores in } \\
\text { average) }\end{array}$ & $\begin{array}{l}\text { Economic resilience } \\
\text { (scores in average) }\end{array}$ \\
\hline Bangladesh & 50 & 36 & 53 & 46 \\
\hline India & 44 & 62 & 56 & 54 \\
\hline Myanmar & 51 & 49 & 32 & 44 \\
\hline Sri Lanka & 62 & 53 & 50 & 55 \\
\hline Thailand & 51 & 72 & 65 & 63 \\
\hline
\end{tabular}

Table 2: Economic Resilience (Digits indicate navigation safety in waters: ascending from dangerous to safe (0 to 100)) ${ }^{2}$

\begin{tabular}{|l|l|l|l|l|}
\hline $\begin{array}{l}\text { Littoral } \\
\text { Countries }\end{array}$ & $\begin{array}{l}\text { International } \\
\text { Cooperation } \\
\text { (scores in average) }\end{array}$ & $\begin{array}{l}\text { Rule of Law (scores } \\
\text { in average) }\end{array}$ & $\begin{array}{l}\text { Maritime } \\
\text { Enforcement } \\
\text { (scores in average) }\end{array}$ & $\begin{array}{l}\text { Good Governance } \\
\text { (scores in average) }\end{array}$ \\
\hline Bangladesh & 88 & 40 & 69 & 66 \\
\hline India & 88 & 62 & 74 & 75 \\
\hline Myanmar & 94 & 49 & 60 & 68 \\
\hline Sri Lanka & 100 & 61 & 63 & 75 \\
\hline Thailand & 88 & 55 & 69 & 71 \\
\hline
\end{tabular}

Table 3: Good governance (Digits indicate navigation safety in waters: ascending from dangerous to safe (0 to 100)) $)^{3}$

Bangladesh: Rohingya refugee situation creates instability in Bangladesh's law and enforcement. Bangladesh is under a threat of piracy and armed robbery compared to other BoB states diminishing the safety of navigation in their territorial waters.

\footnotetext{
${ }^{1}$ Data: Maritime security index, 2019

2 Data: Maritime Security Index, 2019

${ }^{3}$ Data: Maritime security Index, 2019
} 
Kidnapping fishermen for ransom created fear in fisheries communities and impacted the economic resilience of the families. However, overall fishery and blue economy management have been improved significantly, though coastal welfare still needs improvements. As a result, the blue economy became a significant priority and changed the overall ocean governance in Bangladesh. Affiliation to IORA also increased the level of international cooperation and subsequently increased the integrity of Bangladesh's Marine enforcement.

India: India has taken enormous initiatives at all levels, international, national, regional, sub-regional and bilateral, which has provided India's government with a leadership position in protecting maritime security. India has invested resources in several different sea projects to boost the maritime-related affairs of the country.

Myanmar: Myanmar has developed maritime security along with economic resilience significantly in recent years. Myanmar has reformed its internal politics by supporting non-littoral and western countries, which has given economic and geopolitical resilience to Myanmar by strengthening its naval capabilities (Gamage, 2021). At the same time, the political, economic and social crisis in Myanmar led to weakening of offence prevention in navigation and subsequently to a sharp increase in illicit trades cases. Increased commerce in guns, narcotics, and synthetic drugs constituted a serious maritime concern for Myanmar (Benson, 2020). The country is now the world's biggest producer of the highly addictive and widely used synthetic substance yaba. Myanmar has attempted to stop the flow of illegal substances out of the country, but criminals continue to do so across Southeast Asia. As a result, the rate of navigation safety in the category of illicit trades resilience has declined drastically since 2019. (Benson, 2020).

Sri Lanka: Sri Lanka has been increasing multisectoral cooperation for strengthening maritime-related affairs, especially focusing on policies after the fisheries dispute 2016 with India. (Gamage, 2021). At the same time, due to high rates of illicit trade induced by the trade in gold and counterfeit agricultural products, Sri Lanka's navigation safety rating was below average. The government has been careful to maintain an adequate maritime presence since the end of the Sri Lankan Civil War in 2009 (Benson, 2020). Furthermore, as the Bay of Bengal report shows, permitting illicit actors full reign in the marine domain can have a significant impact on maritime security (Benson, 2020).

Thailand: Thailand has secured its maritime boundary by pursuing multilateral maritime cooperation in various maritime-related matters, likely trade and connectivity in terms of secure maritime zone. Bilateral cooperation and negotiation with India and Myanmar provide a dominant cooperation mode for ensuring different cooperation measures within and beyond the sub-region. For example, Thailand invested ventures in cooperation projects in maritime security awareness (Gamahe, 2021). Nowadays, Thailand struggles with maritime mixed migration, especially in maritime trafficking. 
Landless Cambodians seeking urban employment prospects in Thailand to improve their living standards, as well as ethnic Rohingya refugees fleeing Myanmar's Rakhine state (Benson, 2020). Migration patterns can generate maritime risks, as the maritime security report "Stable Seas: Bay of Bengal" notes, if extensive surveillance and proper documentation are lacking (Benson, 2020).

\section{Evaluation on collectivist approach towards BoB}

Supporters of collectivism, such as Markus, Kitayama, and DuBois, pointed out that the notion of collectivism emphasizes interdependence. Countries with collectivist cultures are more likely to "view themselves as connected to others, define themselves in terms of relationships with others, and perceive their qualities as more likely to vary across situations" (AFS, 2019). Maintaining social peace, getting along with others, and achieving common expectations, on the other hand, are more important in collectivist cultures (AFS, 2019). Within the collectivist notion, there is a tendency to cooperate in indirect styles - collectivists indicate what they truly intend but may say otherwise to avoid confrontation or humiliation. It's also worth noting that in terms of social, cultural, and economic factors, the Asian continent is more collectivist.

At the same time, within the BoB international cooperation, the policies, attitudes and opinions of the member-states sometimes are distinct from each other impede the collectivist approach towards overall maritime security-related affairs. Such differences have been caused mainly because some of the member-states are already in better positioning. Especially it can be traced within the BIMSTEC cooperation. Thailand and Myanmar are both members of the Association of Southeast Asian Nations (ASEAN), which is often regarded as a successful regional organization (Wagner and Tripathi, 2018). Intraregional commerce between ASEAN member states accounted for roughly $29 \%$ of overall commodities trade prior to the epidemic (Wagner and Tripathi, 2018). The South Asian Association for Regional Cooperation (SAARC), which includes Bangladesh, Bhutan, India, and Nepal, is regarded a reasonably unsuccessful model of regional cooperation in Asia (Wagner and Tripathi, 2018). Intraregional commerce is only $7 \%$ of total trade (Wagner and Tripathi, 2018). Furthermore, wars between India and Pakistan (Indo-Pak) have often impeded the organization's expansion. As a result, there has been no regional cooperation in South Asia that adequately addresses the collectivist approach's main features. Nonetheless, due diligence has always been a consideration for the BoB worldwide management. 


\section{Conducting maritime due diligence: a comprehensive approach}

Due diligence is the obligation imposed upon states to take measures to protect persons or activities inside or beyond their respective territories to prevent harmful events and outcomes (International Court of Justice, 1949): "every State's obligation not to allow knowingly its territory to be used for acts contrary to the rights of other States (International Court of Justice, 1949)." Due diligence on maritime security of the Bay of Bengal for the protection of vessels both nationally and internationally is the study area of the research. The concept of due diligence has exceptional value for the coastal countries of the Bay of Bengal, as they are using and utilizing their seas for exploring the state's blue economy as the source of macroeconomic growth. However, maritime security across the Bay remain questionable and challenging for the coastal states. Piracy, terrorism, illegal migration, marine pollution and other political violence created a threat for coastal communities and required a due diligence criterion applied in assessing the obligation of coastal states on maritime security of the Bay of Bengal.

Due diligence within international law can play a crucial role in codifying state responsibilities, international liabilities of the states, and identifying the threats that caused damage to the maritime security of these coastal states. Due diligence in this regard is a process that does not require similar measures from all states (Koivurova, 2006). So, incorporation of the due diligence concept into domestic legislation can additionally contribute to their protection capacities. For example, the Netherlands introduced mandatory due diligence into domestic legislation to prevent child labour (Macchi and Bright, 2020). The Dutch Child labour due diligence law will come into effect in mid-2022. The law introduces a duty for companies providing goods and services to the Dutch end-users to undertake due diligence in order to identify and address the risk of child labour in their supply chains (Macchi and Bright, 2020). In analogy with mentioned law, the law obliging the maritime authorities to provide information on combatting piracy and illegal trade - reflecting due diligence concept, may appear helpful for not only increasing efforts of maritime authorities in ensuring the safety of navigation in territorial waters but also for increasing awareness of potential operators about the safety of navigation. So, due diligence is the procedural obligation of duty bearers.

International Organizations have immunities to enjoy and have no right to abuse these immunities. International law commission adopted draft articles on the responsibility of international organisations, with commentaries.

Article $63 \mathrm{~A} / 66 / 10$ of this draft says, "effect of this part is without prejudice to the international responsibility of the international organization which commits the act in question or of any State or other international organization (UN, 2011)." 
Member states can apply for the introduction of due diligence obligations from third parties of international organisations once they cause harm (Daugirdas, 2020).

The responsibilities of international organisations have general cross-cutting obligations. Contrarily, the international organisations can dispute obligations derived from due diligence in domestic courts or other fora if the client's state is at environmental and social risks, which cause harm to the sustainability framework of International organisations (Campbell et al., 2018).

For example, International Finance Corporation (IFC) enjoys immunities under the environmental and sustainability policy. Article 6 of its agreement gives IFC due diligence responsibility to supervise and ensure members' performances.

This monitoring right IFC adhere upon signing the legal agreement to dispute if its members' rights are damaged or in a case of transboundary harms or member states fail to adhere commitments (Young, 2012).

Based on reviewing the maritime security management system, it is possible to conclude that the BoB zone is vulnerable in finding a sustainable and long-term solution for a holistic approach to policymaking.

Threats and diverse challenges demand an assessment on sustainable development that includes sustainable practices for protecting illegal and unsustainable practices by member states (Table 4). 


\begin{tabular}{|c|c|}
\hline $\begin{array}{l}\text { Due Diligence aspects in } \\
\text { BoB zone }\end{array}$ & Marine Security \\
\hline Hypothesis creation: & $\begin{array}{l}\text { - BoB's environmental protection under international environmental law and UNCLOS } \\
\text { Articles } 145,236,237 \text { on the protection and preservation of the marine environment } \\
\text { must be reconciled based on the material treaty, international environmental law } \\
\text { and customary law norms imposing due diligence responsibilities. Every party has } \\
\text { responsibilities and liabilities. } \\
\text { - Protection of human rights under international human rights, International } \\
\text { Humanitarian Law, Article } 146 \text { of UNCLOS protection of human life }\end{array}$ \\
\hline Impact \& Threats: & $\begin{array}{l}\text { - Climate risks: (Basu, 2020) (Chowdhury et al., 2015) } \\
\text { 1) severe cyclones \& thunderstorms } \\
\text { 2) a high sea level \& temperature rise } \\
\text { 3) Flood risks, soil erosion \& landfalls } \\
\text { 4) salinity \& Ocean acidification } \\
\text { - Illegal, Unreported \& Unregulated (IUU) fishing } \\
\text { - Illicit trades \& piracy } \\
\text { - Coastal welfare \& unsustainable tourism industries } \\
\text { - Poor governance: (BIMSTEC) } \\
\text { 1) Poor capacity in International cooperation } \\
\text { 2) Poor judicial integrity } \\
\text { 3) The Weak rule of law \& illicit networking } \\
\text { 4) Poorly managed law of the sea and enforcement } \\
\text { - Imbalance the socio-economic status of the members. }\end{array}$ \\
\hline $\begin{array}{l}\text { Identify state } \\
\text { responsibilities: }\end{array}$ & $\begin{array}{l}\text { - "The responsibility to ensure that activities within their (states) jurisdiction or control } \\
\text { do not cause damage to the environment of other States or of areas beyond national } \\
\text { jurisdiction." (Koivurova, 2006) } \\
\text { - Encourage "International cooperation at all levels, particularly at the regional, sub- } \\
\text { regional and bilateral levels are encouraged by the article } 268 \text { of UNCLOS" }\end{array}$ \\
\hline $\begin{array}{l}\text { Analysis of obligations: } \\
\text { (Kovurova, 2006) }\end{array}$ & $\begin{array}{l}\text { - "State's legal responsibility on the consequent of significant damages caused to the } \\
\text { environment of other States." } \\
\text { - "State's conduct is compared to what a 'reasonable' or 'good.' } \\
\text { - } \quad \text { "government would do in a specific situation of transboundary harm." } \\
\text { - } \quad \text { "State has acted diligently or not". (good \& best evidences) } \\
\text { - } \quad \text { Extra precautions, } \\
\text { - } \quad \text { obligations to cooperate in cases of specific transboundary harm situations } \\
\text { - The concerned States are also obligated to exchange information on preventive duties } \\
\text { where already operative activities are concerned. }\end{array}$ \\
\hline Value creation: & $\begin{array}{l}\text { - } \text { Blue economy brings economic resilience } \\
\text { - } \quad \text { Climate justice } \\
\text { - } \quad \text { Geopolitical context } \\
\text { - } \quad \text { Greater peace and stability of the marine environment }\end{array}$ \\
\hline $\begin{array}{l}\text { Strategic } \\
\text { Determination: } \\
\text { (Mohammad and Ahmad, } \\
\text { 2015) }\end{array}$ & $\begin{array}{l}\text { - Influence, interest and power of littoral and non- littoral countries } \\
\text { - } \quad \text { Maritime presence and growth } \\
\text { - } \quad \text { Projection on capacities, motivation and significant involvement of developing and } \\
\text { geographically disadvantaged states without prejudice under the article } 70 / 6 \text { of UNCLOS }\end{array}$ \\
\hline $\begin{array}{l}\text { The expectation for the } \\
\text { future management }\end{array}$ & 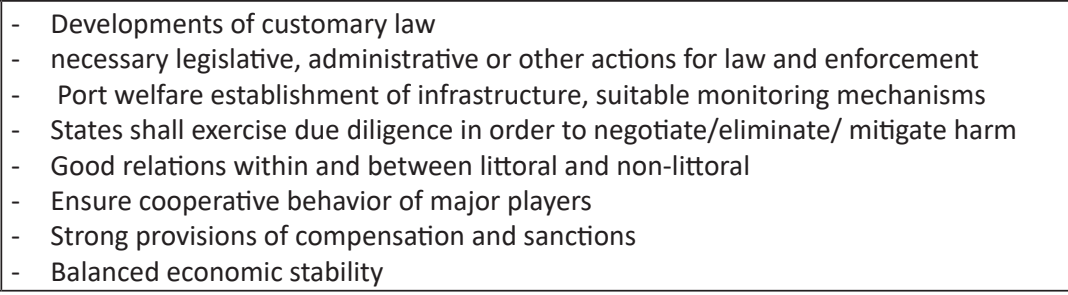 \\
\hline
\end{tabular}




\section{Conclusions}

Blue economy aspects of the BoB zone depend on sustainable corporate governance and actions and mandatory due diligence towards sustainable objectives. However, some countries that are much more active at the international level are supposed to put little more effort into complying with due diligence for protecting the maritime security of this zone.

As we noted in the previous sections of the article, one of the challenges in the governance of the Bay of Bengal is the ineffective management system of the BIMSTEC, including insufficient capacity in International cooperation, poor judicial integrity, the weak rule of law \& illicit networking and poorly managed law of the sea and enforcement. We would recommend explicit incorporation of the due diligence concept to domestic maritime legislation within the BIMSTEC as a way of maintaining states' responsibility to ensure that activities under their jurisdiction or control do not harm the environment of other States or areas beyond national jurisdiction.

ASEAN activated due diligence for identifying and response fraud and risks, targeting transparent governance and the rule of law in Southeast Asia. (ASEAN, 2021) However, some of the littoral countries of the Bay of Bengal are not an official part of ASEAN, creating a challenge in successful combating unhealthy practices of the blue economy of those countries that are not part of ASEAN. An independent international body for ensuring due diligence for hindering systematic barriers of BoB littoral countries could truly balance the need of the littoral countries for their economic growth. Regional governments of the littoral countries need to follow collectively planned and managed systems to control regional activities, facilitating vigorous marine management. A due diligence guideline is essential for raising awareness of the private sector and governments regarding sustainable business behavior in the region and maritime protection of the Bay of Bengal.

\section{Bibliography}

1. ASEAN (2021) 'Due Diligence in ASEAN', ASEAN Briefings. Jakarta: ASEAN. Available at: https://www.aseanbriefing.com/news/due-diligence-in-asean/ (Accessed: 20 December 2021).

2. Attri, V. N. and Bohler-Muller, N. (2018) The Blue Economy Handbook of the Indian Ocean Region. Pretoria: Africa Institute of South Africa Press.

3. Basu, J. (2020) 'Bengal most Vulnerable to climate risk, flags India's first assessment report', Down to Earth, Available at: https://www.downtoearth.org. in/news/climate-change/bengal-most-vulnerable-to-climate-risk-flags-india-sfirst-assessment-report-72117 (Accessed: 20 December 2021). 
4. Benson, J. (2020) Stable seas: Bay of Bengal. Cape Town: Stable Seas. Available at: https://www.stableseas.org/post/stable-seas-bay-of-bengal (Accessed: 20 December 2021).

5. Bhaumik, A. (2018) India wants Bay of Bengal to be "common security space". Bangalore: Deccan Herald. Available at: https://www.deccanherald.com/ national/india-wants-bay-bengal-be-688774.html (Accessed: 20 December 2021).

6. BIMSTEC (2018) Fourth BIMSTEC Summit Declaration. New Delhi: Ministry of External Affairs of India. Available at: https://mea.gov.in/bilateraldocuments.htm?dtl\%2F30335\%2FFourth_BIMSTEC_Summit_Declaration_ August_3031_2018 (Accessed: 20 December 2021).

7. Bose, S. (2020) 'BIMSTEC and Disaster Management: Future Prospects for Regional Cooperation', ORF Issue Brief, 383. New Delhi: Observer Research Foundation.

8. Bueger, C. and Edmunds, T. (2017) 'Beyond sea blindness: a new agenda for maritime security studies', International affairs, 93(6), pp. 1293-1311. Oxford: Oxford University Press.

9. Bueger, C. and Singh Saran, M. (2012) Finding a regional solution to piracy: is the Djibouti Process the answer? Copenhangen: SAFE SEAS. Available at: http://www.safeseas.net/finding-a-regional-solution-to-piracy-is-the-djiboutiprocess-the-answer/ (Accessed: 18 December 2021).

10. Campbell, E., Dominic, E., Stadnik, S. and Wu, Y. (2018) Due Diligence obligations of international organisation under international law. Available at: https:// www.nyujilp.org/wp-content/uploads/2018/07/NYI204.pdf (Accessed: 18 December 2021).

11. Chaudhary, A (2021) Landlockedness, Corruption, and Economic Growth in BIMSTEC. Available at: https://www.researchgate.net/publication/349227749_ Landlockedness_Corruption_and_Economic_Growth_in_BIMSTEC (Accessed: 18 December 2021).

12. Chiodi, G. (2018). Interpreting Global Land and Water Grabbing through Two Rival Economic Paradigms. Academicus International Scientific Journal, 9(18), 42-52.

13. Chowdhury, S. R., Shahadat, H. M., Subrata, S. and Sharifuzzama, S. M. (2015) Vulnerabilities of the Bay of Bengal to Ocean Acidifiation. Dhaka: IUCN Bangladesh. Available at: https://portals.iucn.org/library/node/45881 (Accessed: 18 December 2021).

14. Constantino, X. (2018) India attempts to empower BIMSTEC after realising its limitations. Washington: Brookings. Available at: https://www.brookings.edu/ 
opinions/india-attempts-to-empower-bimstec-after-realising-its-limitations/ (Accessed: 18 December 2021).

15. Culture Points, AFS (2019) Individualism and Collectivism. New York: AFS. Available at: https://www.afsusa.org/study-abroad/culture-trek/culturepoints/culture-points-individualism-and-collectivism/ (Accessed: 18 December 2021).

16. Daci, J. (2012). Protection of the Human Right to Water Under International Law-The Need for a New Legal Framework. Academicus International Scientific Journal, 3(06), 71-77.

17. Daugirdas, K. (2020) Member States' Due Diligence Obligations to Supervise International Organisations. Amsterdam: Elsevier. Available at: https://papers. ssrn.com/sol3/papers.cfm?abstract_id=3539181 (Accessed: 18 December 2021).

18. Delhi Consensus (2019) 6th Indian Ocean Dialogue. Sydney: Department of Foreign Affairs and Trade, Australian Government. Available at: https://www. dfat.gov.au/sites/default/files/delhi-consensus-6th-idian-ocean-dialogue.pdf (Accessed: 18 December 2021).

19. Food and Agriculture Organization of the United Nations Office of Evaluation (2016) Final evaluation of Sustainable Management of the Bay of Bengal Large Marine Ecosystem (BOBLME) project. Rome: Food and Agriculture Organization. Available at: http://www.fao.org/3/bd470e/bd470e.pdf (Accessed: 17 December 2021).

20. Gamage, R. (2017) 'Maritime security governance prospects in the bay of Bengal', East Asia Forum. Jakarta: East Asia Forum. Available at: https://www. eastasiaforum.org/2017/02/17/maritime-security-governance-prospects-inthe-bay-of-bengal/ (Accessed: 17 December 2021).

21. Gamage, R. (2017) Bay of Bengal: What implications for ASEAN. New York: Jstor. Available at: https://www.jstor.org/stable/pdf/resrep05888.12.pdf (Accessed: 17 December 2021).

22. Godbole, S. (2018) Revival of BIMSTEC at the Khathmandu Summit. Washington: Brookings. Available at: https://www.brookings.edu/blog/upfront/2018/08/29/revival-of-bimstec-at-the-kathmandu-summit/ (Accessed: 17 December 2021).

23. International Court of Justice (1949) 'Corfu Channel case (UK v Albania), Judgment', ICJ Reports 1949. The Hague: International Court of Justice. Available at: https://www.icj-cij.org/public/files/case-related/1/001-19490409-JUD-0100-EN.pdf (Accessed: 18 December 2021).

24. IORA (2019) Third IORA Ministerial Blue Economy Conference. Quatre Bornes: Indian Ocean Rim Association. Available at: https://www.iora.int/en/events- 
media-news/news-updates-folder/third-iora-ministerial-blue-economyconference (Accessed: 20 December 2021).

25. Iyer, G. (2017) 'Common responses to maritime security threats in the Bay of Bengal', ORF Issue Brief. New Delhi: Observer Research Foundation. Available at: $\quad$ https://www.orfonline.org/research/common-responses-maritimesecurity-threats-bay-of-bengal/ (Accessed: 17 December 2021).

26. Karim, T. (2021) 'The Importance of the Bay of Bengal as a Causeway between the Indian and Pacific Oceans', Asia Pacific Bulletin, 557. Honolulu: EastWest Center. Available at: https://www.eastwestcenter.org/publications/ importance-the-bay-bengal-causeway-between-the-indian-and-pacificoceans (Accessed: 20 December 2021).

27. Khurshed, A. M. (n/d) Maritime safety and security in the Bay of Bengal. Dhaka: BSMRMU. Available at: https://bsmrmu.edu.bd/public/files/ econtents/5eb7aaa6b0958bmj-03-01-02.pdf (Accessed: 17 December 2021).

28. Koivurova, T. (2006) 'Due Diligence', Max Planck Encyclopedia of Public International Law. Oxford: Oxford University Press. Available at: https://www. arcticcentre.org/loader.aspx?id=78182718-d0c9-4833-97b3-b69299e2f127 (Accessed: 17 December 2021).

29. Levy, J. S. and Thompson, W. R. (2010) 'Balancing on land and at sea: do states ally against the leading global power?', International Security, 35(1), pp. 7-43. Cambridge: MIT Press.

30. Macchi, C. and Bright, C. (2020) 'Hardening Soft Law: The Implementation of Human Rights Due Diligence Requirements in Domestic Legislation', Legal Sources in Business and Human Rights - Evolving Dynamics in International and European Law. Amsterdam: Elsevier.

31. Mohammad, H. K. and Ahmad, A. (2015) 'The Bay of Bengal: Next theatre for strategic power play in Asia', Croatian International Relations Review, 22, pp. 199-239. Available at: https://www.researchgate.net/publication/276511646_ The_Bay_of_Bengal_Next_Theatre_for_Strategic_Power_Play_in_Asia (Accessed: 17 December 2021).

32. Rahman, M. R. (2017) 'Blue Economy and Marine Cooperation in the Bay of Bengal: Role of Bangladesh', Procedia Engineering, 194, pp. 356-361. Amsterdam, Netherlands: Elsevier.

33. Rahman, M. R. (2017) 'Blue Economy and Maritime Cooperation in the Bay of Bengal: Role of Bangladesh', Procedia Engineering, 194, pp. $356-361$. Amsterdam: Elsevier. Available at: https://www.sciencedirect.com/science/ article/pii/S1877705817333088 (Accessed: 20 December 2021).

34. Reinisch, A. (2005) The changing international legal framework for dealing with non-state actors, in non-state actors and human rights. Oxford: Oxford 
University Press. Available at: https://www.univie.ac.at/intlaw/reinisch/non_ state_actors_alston_ar.pdf (Accessed: 17 December 2021).

35. Sakhuja, V. (2014) Blue Economy: An Agenda for the Indian Government. New York: Center for International Maritime Security. Available at: http:// www.maritimeindia.org/CommentryView.aspx?NMFCID=137 (Accessed: 20 December 2021).

36. Singh, A. (2020) 'Towards an Integrated 'Blue Economy' Framework in the Bay of Bengal', ORF Issue Brief, 411. New Delhi: Observer Research Foundation. Available at: https://www.orfonline.org/research/towards-an-integrated-blueeconomy-framework-in-the-bay-of-bengal/ (Accessed: 20 December 2021).

37. United Nations (2011) 'Draft articles on the responsibility of international organisations, with commentaries', Yearbook of International Law Commission, 2(2). Available at: https://legal.un.org/ilc/texts/instruments/english/ commentaries/9_11_2011.pdf (Accessed: 17 December 2021).

38. World Bank (2017) The potential of the Blue Economy. New York: International Bank for Reconstruction and Development/The World Bank. Available at: https:// openknowledge.worldbank.org/bitstream/handle/10986/26843/115545. pdf?sequence=1\&isAllowed=y (Accessed: 20 December 2021).

39. Young, A. (2012). 'Deconstructing International Organization Immunity', Georgetown Journal of International Law, 44(1). Washington: Georgetown University Law Center. Available at: https://papers.ssrn.com/sol3/papers. cfm?abstract_id=2251976\# (Accessed: 16 December 2021). 